\title{
The Correlation Noun Phrase and Writing of Descriptive Text at Tenth Level Students of SMA N 5 OKU
}

\author{
Mila Arizah. Universitas Baturaja \\ milaarizah1984@gmail.com
}

Tri Molly Ramadhona tri.mollyr@gmail.com

\begin{abstract}
Abstrak
Penelitian bertujuan untuk mencari tahu apakah terdapat hubungan yang signifikan antara Noun Phrase dan penulisan teks deskriptif. Penelitian ini menggunakan pendekatan kuantitatif. Teknik untuk mengumpulkan data adalah tes frase kata benda dan tes tertulis. Penelitian ini dilakukan di SMA N 5 OKU. Populasi penelitian ini adalah siswa kelas $X$ SMA N 5 OKU tahun akademik 2018/2019 dan sampelnya adalah 122 siswa yang dipilih secara acak dari populasi. Data dikumpulkan dengan menggunakan noun phrase test dan tes tertulis. Data dianalisis dengan menggunakan analisis korelasional dan terkomputerisasi dengan menggunakan SPSS 23. Setelah melakukan penelitian, peneliti mendapatkan data yang menunjukkan bahwa ada korelasi yang signifikan antara frasa kata benda dan penulisan teks deskriptif. Korelasi signifikan dalam hal koefisien korelasi adalah 0,424. Ini berarti hipotesis penelitian ( $\mathrm{Ha}$ ) hipotesis alternatif diterima dan (Ho) hipotesis nol ditolak.
\end{abstract}

Kata Kunci: Korelasi, Frasa Kata Benda, Penulisan Teks Deskriptif

\section{INTRODUCTION}

\subsection{Background}

In Indonesia, English as we know is learnt and taught to elementary school, junior high school, senior high school until at university. It meant that English is important for the students to be taught at school based on situation and condition of the object area. In elementary schools, English has to introduce as a local content subject. The main purpose in teaching English in Indonesia is that the students are able to use the English language to communicate each other both orally and writing. To achieve the objective, there are several skill that the students have to master the four language skills, they are listening, speaking, reading and writing..

Writing is the expression of language in the form of letters, symbols, or words. According to Jackson (2005) cited in Wijayanti
(2016) stated that writing is the physical act of committing words or ideas to some medium. Writing should be mastered by the students in order to make them share their ideas correctly and understandable.

Based on the definition above, that writing is a communicating ideas and information, form of writing such as a tracing a character on paper, symbols, number, or word and sentences. Also should be understanding by the students correctly. Descriptive is kind of genre used to explain person, place, or thing in general. The generic structure of this text are identification and descriptions. The language features of this text involves using simple present tense, adverb, action verb, words of description or adjective.

According to Beare (2003) cited in Udien (2014) state that a descriptive writing is the clear description of people, places, objects, 
or events using appropriate details. Details are used usually sensory and selected to describe what the writer sees, hears, smells, touches and tastes. An affective description will contain sufficient and varied elaboration of details to communicate a sense of the subject being described descriptive text is a text which portrays the image of a certain thing from which a researcher wants to transfer it to readers. Mostly descriptive texts depict or describe the image of a certain person, animal, things, and location or place.

According to Jaya, et al (2009) cited in Maghviroh (2014) state that noun phrase in noun that given modifier although before or after noun which form a new meaning. To make a noun phrase people must have a noun as head word and adding with some modifiers.

The goal of curriculum that students of Indonesia should be able use English for communication both in spoken and written form. In teaching learning process most of students found difficulties because English has so many differences in grammar, spelling, and vocabulary and four language namely speaking, reading, listening, and writing. However, students do not master the for English skills very well, especially in writing skill. The students should be able to communicate in oral and written text, by using English, in form of descriptive, narrative, analytical exposition, and hortatory exposition text.

\subsection{Research Question}

Based on the explanation above, the researcher wanted to find out the correlation between noun phrase and writing of descriptive text of tenth level students of SMA N 5 OKU.

\section{RESEARCH METHOD}

The design of the research was correlation research. According to Creswell (2005) correlation research described and measured the degree of relationship between two or more variables. In conducting the research, the researcher used descriptive quantitative method.

\subsection{Sample of Research}

The sample is a smaller group or part of the total population (Fraenkell and Wallen (2009). For the sampleof this study, the researcher use simple random sampling.

\subsection{Collecting Data}

In collecting the data of this research, the researcher used noun phrase test and written test.

\subsubsection{Noun Phrase Test}

The researcher used noun phrase test to measure students' noun phrase mastery in the sentences. In the noun phrase test, the students should wrote their name and their class clearly on paper first, their time was about 45 minute and work individually. In this test, the researcher used expert judgement to appropriate the ability of noun phrase to the tenth grade students. The researcher had chosen one of English teacher of SMA N 5 OKU named Mrs. Irma Purwati, S.Pd as expert judgement. In this test got 25 items. This research was ready-made test that taken from Kementerian Pendidikan dan Kebudayaan Republik Indonesia 2014, first Edition, Kurikulum 2013 (SMA/MA, SMK/MAK Kelas X, Semester 1).

\subsubsection{Written Test}

The researcher used written test to measure students' writing ability in descriptive text. In written test, the students should wrote their name and their class clearly on paper first, 
their time was about 60 minute, consist of 200250 words, made the sentences into at least two paragraphs and work individually. The researcher gave the students to write a descriptive text which the topics about Taman Kota in Baturaja, Islamic Center in Baturaja and my school. The students chose one topic to describe it. The researcher wrote and checked the students' writing by using rubric of writing assessment. In this test, the researcher used two raters to help assess the result of students written test. The first rater was Mrs. Yunda Lestari, M.Pd from Baturaja University and the second rater was Mrs. Irma Purwati, S.Pd from English teacher of SMA N 5 OKU.

\section{ANALYZING DATA}

\subsection{Data of Noun Phrase Test}

The researcher used descriptive analysis technique. The data is in the form of score. To get individual score, the researcher supplied the following formula, the formula as follow:

$$
\mathrm{S}=\frac{\mathrm{R}}{\mathrm{N}} \times 10
$$

Where:

$\mathrm{S}=$ Test score

$\mathrm{R}=$ Number of right answer

$\mathrm{N}=$ Number of test item

Source: Purwanto (2010)

\subsubsection{Percentage the Data}

In this investigations the data was collect analyze by using the percentages technique.

\subsubsection{Students Average Score}

After scoring the test, the researcher classified the students' answer into several categories and also classified the result of test according to the score as below:

\section{Score Range and Criteria of Noun Phrase Test}

\begin{tabular}{ccc}
\hline No & Score Range & Score \\
\cline { 3 - 3 } & & Criteria \\
\hline 1 & $80-100$ & Very Good \\
\hline 2. & $70-79$ & Good \\
\hline 3. & $60-69$ & Sufficient \\
\hline 4. & $50-59$ & Poor \\
\hline 5. & $<49$ & Very poor \\
\hline \multicolumn{2}{l}{ Source: Sudijono $(2008)$} &
\end{tabular}

\subsubsection{Data of Written Test}

In the researcher, the researcher used criteria of the test. To get students score in writing rubric on descriptive writing rubric below:

Rubric of Writing Descriptive Text

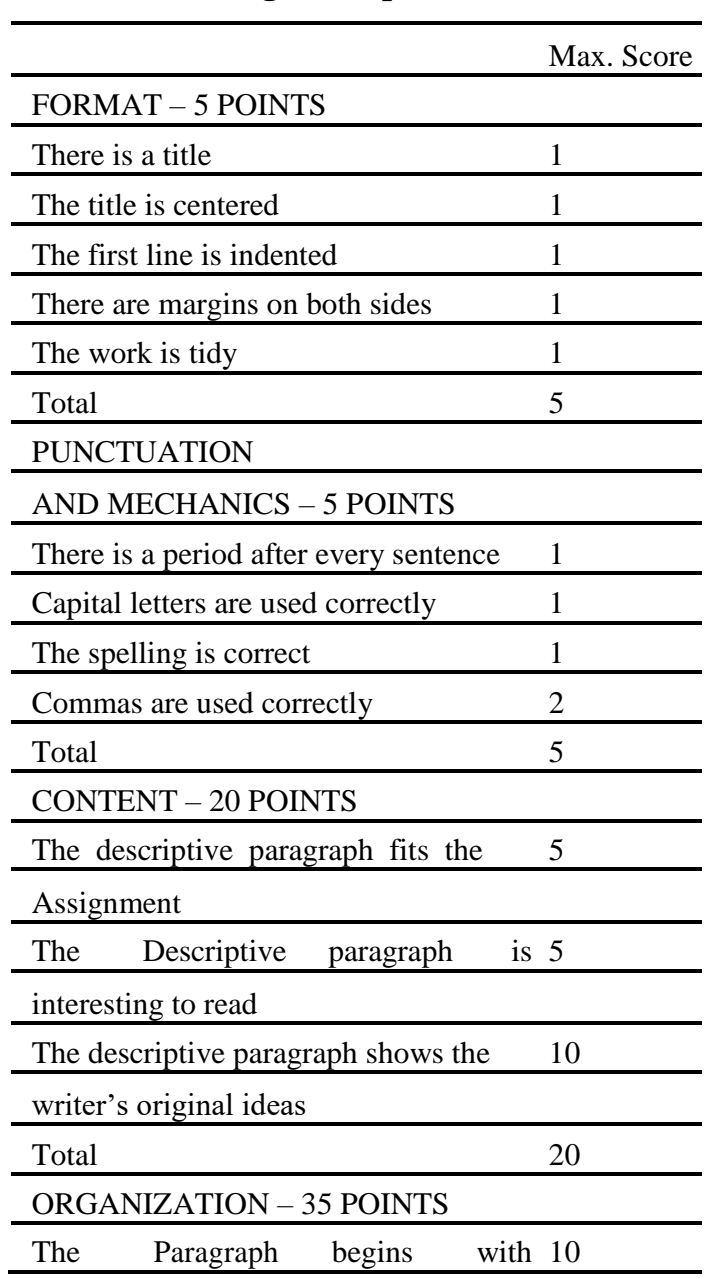




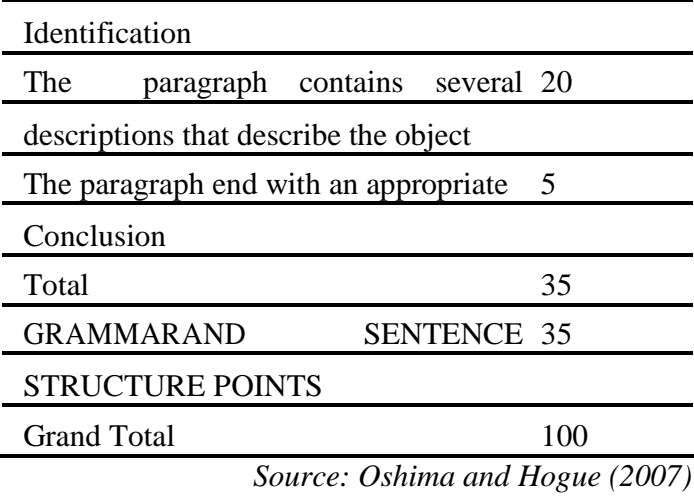

The highest score of them is 100 . If the student got 5, 5, 20, 35, 35 from every criteria of the test, the total score that was 100 . Then, to know score the researcher used this form:

$$
\begin{aligned}
& \mathrm{S}=\frac{\mathrm{R}}{\mathrm{N}} \times 100 \\
& \text { Where: } \\
& \mathrm{S} \quad=\text { Test score } \\
& \mathrm{R}=\text { Number of right answer } \\
& \mathrm{N}=\text { Number of test items }
\end{aligned}
$$

\subsubsection{Score Range and Criteria}

The researcher used the score range and score criteria. It shown on the following table:

Tabel Score Range and Criteria of Written Test

\begin{tabular}{cll}
\hline No & Score Range & Score Criteria \\
\hline 1 & $80-100$ & Very Good \\
\hline 2 & $70-79$ & Good \\
\hline 3 & $60-69$ & Sufficient \\
\hline 4 & $50-59$ & Poor \\
\hline 5 & $<49$ & Very poor \\
\hline & & Source : Sudijono (2008)
\end{tabular}

\subsubsection{The Students Percentage}

The data was obtained from the result of the test by using percentage analysis. The formula was shown bellow:

$$
\mathrm{P}=\frac{\mathrm{F}}{\mathrm{N}} \times 100
$$

Where:

$$
\begin{aligned}
& \mathrm{P}=\text { Persentage } \\
& \mathrm{R}=\text { Frequency of students score } \\
& \mathrm{N} \quad \text { T Total of students }
\end{aligned}
$$

Source : Sudijono (2008)

\subsubsection{Pearson Product Moment Correlation}

For the coefficient correlation between 2 variables $(\mathrm{X})$ and $(\mathrm{Y})$, the researcher analyzed data by using SPSS 23. In the correlation technique, the variable were compared to know whether the correlation was very significant or it only happen by chance. There was interpretation coefficient correlation to know the level of correlation were presented in table:

\section{Score Range and Criteria of Correlation}

\begin{tabular}{ll}
\hline Correlation value & Interpretation \\
\hline $0.00-0.20$ & Very low \\
\hline $0.20-0.40$ & Low \\
\hline $0.40-0.70$ & Moderate \\
\hline $0.70-0.90$ & High (good) \\
\hline $0.90-1.00$ & Very good \\
\hline \multicolumn{3}{c}{ Source : Sudijono (2009) } \\
IV. & RESULT, \\
\multicolumn{3}{c}{ FINCUSSION }
\end{tabular}

The researcher conducted the test to order find out the students ability in noun phrase. The test was given on July $31^{\text {st }}-$ August $2^{\text {nd }}, 2018$. The total number of students was 122 students. This part described the result of the test which aimed to find out the students ability in noun phrase of the tenth grade students of SMA N 5 OKU. Based on the descriptive statistical analysis of noun phrase for the participants above, the mean score of noun phrase was 67.42 , the minimum score was 20, and the maximum score was 95 . Meanwhile, the mean of standard deviation 14.102. The mean score (67.42) indicated that the level of noun phrase of tenth student was 
sufficient. it was found that the students who got very good criteria, was reached by 26 students. The students who got good criteria, it was reached by 42 students. The students who got sufficient criteria, it was reached by 30 students. Then for the students who got poor criteria, it was reached by 15 students. The very poor criteria, it was reached by 9 students.

Chart 1

Students Distribution

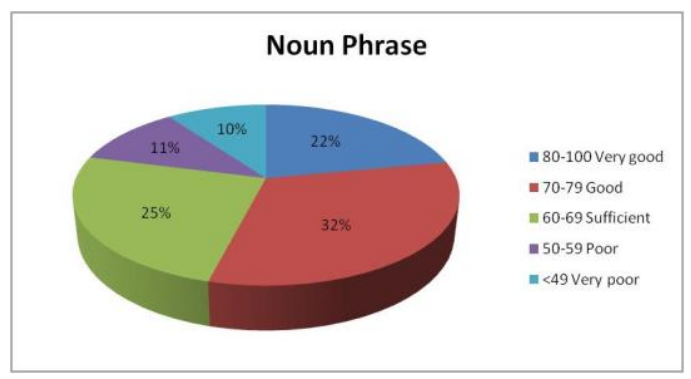

Based on the descriptive statistical analysis of writing descriptive text for the participants above, the mean score of writing descriptive text was 61.72 , the minimum score was 30, and the maximum score was 75 . Meanwhile, the standard deviation was 8.879 . The mean score (61.72) indicated that the level of writing descriptive text of students was sufficient.

Chart 2

Students Distribution



The interpretation are made by the result of data analysis in order to strengthen the value of this strengthen the value of this research. From the analysis of the result of noun phrase and writing descriptive text test, the result of the correlation between noun phrase and writing descriptive text showed the table above that there was significant correlation.

The result of Pearson Product Moment correlations was found that there significant correlation ( $r$-.424). Based on the descriptive statistical analysis of noun phrase for the participants above, the mean score of noun phrase was 67.42 , the minimum score was 20 , and the maximum score was 95. Meanwhile, the standard deviation was 14.102 . The mean score (67.42) indicated that the level of noun phrase of tenth students was sufficient.

Based on the descriptive statistical analysis of writing descriptive text for the participants above, the mean score of writing descriptive text was 61.72 , the minimum score was 30, and the maximum score was 75 . Meanwhile, the standard deviation was 8.879 . The mean score (61.72) indicated that the level of writing descriptive text of tenth students was sufficient.

Based on result above, the researcher concluded if the students had high the mastery of noun phrase would had a high writing ability of descriptive text too.

Based on explanation above it was found that the obtained correlation coefficient was 0.424 with $\mathrm{N}=122$.According to Cohen (2005) and Creswell (2012) if the value of $r$ obtained was between 0 to +1.0 would indicated positive correlation between two factors and the value of $r$-obtained was (.424) a moderate correlation. So the result indicated that there was a positive significant correlation between the mastery of noun phrase and writing ability of descriptive text. Based on the correlation value by Sudijono (2009), the degree of correlation value $0.40-0.70$ was moderate correlation. 


\section{CONCLUSION}

The conclusion of findings and interpretation there was significant correlation between the mastery of noun phrase and writing ability of descriptive text. Based on score criteria of correlation, the value of correlation between the mastery of noun phrase and writing ability of descriptive text was positive moderate correlation, the value of $r$-obtained was (.424). The degree of correlation coefficient $(0.40-$ 0.70). It meant that Ha was accepted and Ho was rejected. So, the students who have high noun phrase should logically have good in writing descriptive text. And the students who have low noun phrase level, will get the low in writing descriptive level too.

\section{REFERENCES}

Arikunto, Suharsimi. (2010). Prosedur penelitian suatu pendekatan praktik. Jakarta: Rineka Cipta.

Anisa, Nurul. (2015). The correlation between students' grammar ability and their writing in short narrative text to the eighth grade students at SMP N 4 $O K U$. Unpublished undergraduate thesis, Baturaja University, Faculty of Teacher Training and Education, Baturaja, Indonesia.

Creswell, John W. (2005). Educational research: planning, conducting, and evaluating quantitative and qualitative research $\left(2^{\text {nd }} e d\right)$. Pearson Education: Merrill Prentice Hall.

Cohen, L., L. Manion, \& K. Morrison (2007). Research methods in education New York: Routledge Falmer.

Fraenkle, Jack R and Norman E, Wallen. (2009). How to design and evaluate research in Education $7^{\text {th }}$ edition. New York: Mc Graw-Hill, Icn.

Marti. (2013). The correlation between the students' writing ability and their grammar mastery of the second year students of SMA $N \quad 8 \quad O K U$. Unpublished undergraduated thesis, Baturaja University, Faculty of Teacher training and Education, Baturaja, Indonesia.

Maghviroh, S.U. (2014). Students' comprehension of noun phrase plus adjective phrase towards students' writing skills. Unpublished ungraduate thesis, STAIN Salatiga, English Department of Educational Faculty, Salatiga, Indonesia.

Oshima, A. \& Hogue, A. (2007). Introduction to academic writing. NY: Pearson education inc.

Priyana, Joko dkk. (2008). BSE. Interlanguage: English for senior high school students X: SMA/MA kelas XI. Jakarta: Pusat Perbukuan, Departemen Pendidikan Nasional

Purwanto. (2010). Prinsip-prinsip dan teknik evaluasi pengajaran. Bandung: Pt. Remaja Rosdakarya.

Sudijono, A. (2015). Pengantar statistik pendidikan. Jakarta: Pt. RajaGrafindo Persada.

Sudijono, A. (2008). Penelitian dan pendididkan. Bandung: Sinar Baru Algesindo.

Wijayanti, I. (2016). The use of phrases to writing descriptive text by the srudents of SMA negeri 1 boyolali in 2015/2016 academic year. Unpublished ungraduate program master of language study surakarta muhammadiyah university. 